This is an author produced version of a paper published in Facilities. This paper has been peer-reviewed but does not include the final publisher proof-corrections or journal pagination.

Citation for the published paper:

Palm, Peter. (2017). Real estate management : incentives for effort.

Facilities, vol. 35 , issue $9 / 10$, p. null

URL: https://doi.org/10.1108/F-05-2016-0046

Publisher: Emerald

This document has been downloaded from MUEP (https://muep.mah.se) / DIVA (https://mau.diva-portal.org). 


\title{
Real Estate Management:
}

Incentives for effort

Peter Palm

peter.palm@mah.se

\begin{abstract}
Purpose - The aim is to examine how the real estate owner (decisionmaker) can ensure that the preferred tasks are prioritised. In particular, the incentives to ensure motivation to perform in order to accomplish the strategic goals of the decisionmaker are investigated.

Design/methodology/approach - This research is based on an interview study of nineteen firm representatives, six decisionmakers and thirteen management representatives, all from the Swedish commercial real estate sector.

Findings - The study conclude that the real estate management organisation in the outsourced management setting is govern by the contract, in detail constituting work tasks, and in the in-house management setting there are a freedom with responsibilities instead of regulations.

Research limitations/implications - The research in this paper is limited to Swedish commercial real estate sector

Practical implications - The insight in the paper regarding how decisionmakers creates incentives for the real estate management organisation in the different organisational settings can provide inspiration to design incentives for effort.

Originality/value - It provides an insight regarding how the industry, depending on organisation setting, prioritise different work tasks and how incentives are created to enable effort.
\end{abstract}

Keywords - Real Estate Management, Incentives, Decision making, Commercial Real Estate,

Paper type Research paper

\section{Introduction}

A central question in real estate is management, if we look at the cost of building and managing real estate, in perspective of the expected life-expectancy of the real estate. In addition, there are questions regarding who should conduct the management, what is the most efficient organisational structure and how should that structure be set to work.

To begin with, a real estate owner has the strategic choice of whether to perform the management by his/herself or to outsource it (See for example Abatecola and Cafferata, 2014). No matter the strategic choice, costs still arise, and the only question is if these costs should be internal or external (Graham et al. 2014 and Klingberg and Brown, 2006). The framework of these costs is known as the principal-agent problem. The problem arises when a service is provided by an employee or by an outside entity (service partner). In this context, the classical problem of finding an incentive to ensure motivation to effort arises, as elaborated by Milgrom and Roberts (1992). This also raises the question regarding incentives and trust as elaborated by Freybote and Gibler (2011)

Previous research has addressed the question of effort and real estate management from either a management perspective (Kadefors, 2008), an outsourcing perspective, if to outsource and 
what to outsource (Hätönen and Eriksson, 2009 and Jensen, 2011), and the relationship between service providers in an outsourcing relationship (Lok and Baldry, 2015). All research above including numerus other studies (see for example Hätönen and Eriksson, 2009 for a historical overview) of outsourcing of the management function all have the perspective of the organisation. But the implications of incentives for effort of the individual real estate manager has not previously been addressed.

This article examines, the question related to the problem of how a real-estate owner as a decisionmaker relying on one or more interested parties, in-house management team or outside service team, can ensure that the preferred tasks are prioritised. In particular, incentives to ensure motivation to perform in order to accomplish strategic goals of the decisionmaker are investigated. The specific research question addressed is how the real estate owner has constructed incentives for the real estate management function to make the right efforts.

The article presents the results of an interview study with six commercial real estate owning companies and their management organisations in Sweden. The study aims at contributing to the body of knowledge on strategic real estate management with a focus on factors regarding incentives for performance.

When considering the real estate industry in Sweden, we can observe a variety of strategic organisations coexisting for many years (Palm, 2013). The conclusion must be that no type of organisational setting, be it in-house or outsourced is superior to the other. In reality, there are only two different ways of organising the real estate management. Rather, the question of success is how to make the owner's strategic goals, carried out within the chosen organisational structure, work. A statement that is supported by the Sanderson's research (Sanderson 2015, 2014, and Sanderson and Edwards 2016, 2014).

\section{Theoretical background}

This section of the article consists of two parts. In the first, the incentive perspective is outlined; thereafter, incentive in the context of real estate management is outlined.

\subsection{The incentive perspective}

Decision making in organisations requires both the allocation of responsibilities and organisational routines together with well-designed contracts that relegate these questions (Milgrom and Roberts, 1986). Research regarding motivation to perform is still dominated by the classical principal-agent model (Marona, 2013). In this model, the principal cannot perfectly monitor the agent who might behave in an opportunistic manner at the expense of the principal (Williamson, 1975). If the work performed by the agent is unobservable and she is paid a flat wage the principle can offer a bonus, tied to the output. In this way the principle can insure the agent will perform in-line with her requirements (Prendercast 1999).

However, Gibbons (1998) states that it is not always possible, or desirable, to design the incentive contract on only a number of produced units. Instead, Gibbons (1998) introduces an alternative performance measure. This measure performance measure takes the different kinds of actions that the agent can take, into account. Here Gibbons (1998) highlights the possibility to weighting the different actions and tie the bonus to how they contribute to firm value.

Baker (1992) concludes that no contract can match the marginal benefits of the agent's different actions. However, Holmström and Milgrom (1991) display different models concerning 
settings with multiple actions. This was something that Lazeer (1989) also highlights in order to include restriction on activities. When two actions compete for the agent's attention. If the agent where to perform one action, then she would have to give up the other action. In particular, if the contractual incentive for the first action, has to compete with the private benefit of conduction of the second action, we will face an incentive problem. But as Gibbons (1998) concludes, if the principal could define the work in a way that it would exclude, or minimize, activities allowed, then the agent's incentive to perform a1 would depend on the bonus rate just as in the original way. The study of Cockburn et al (1999) on pharmaceutical firms' need of both immediate useful output and investment in knowledge in a long-term perspective is a classic example of how incentives will influence actions taken. They conclude that the firm must create strong incentives for both actions, but not necessarily the same kind of incentives.

Baker et al. (1994) add one more dimension to the incentive paradigm: when the agent's contribution is observable, but not verifiable. An example would be Shapiro and Stiglitz's (1994) study regarding how firing could be considered as an action of discipline in the relational contract setting. Baker et al. (1994) introduce the possibility to use both contracts based on objective performance and relational contracts based on subjective assessments. The relational contract can reduce the distortionary incentives that can be created by the formal contract, considering only objective performance. At the same time, the formal contract can reduce the relational-contract bonus that the principal would have to offer if only using a relational contract.

The key benefit of all the above-mentioned models is that they are applicable both within and between firms for a given incentive problem

\subsection{Incentives in real estate management context}

In the real estate manger's everyday duties, the real estate owner has monitoring problems at the same time as the individual manager is responsible for large values (Sirmans et al., 1999). There are risks of opportunistic behaviour as tasks that cannot be observed are neglected in favour of observable or quantitative tasks. The real estate owner stands before the same kind of setting as the pharmaceutical firms (see Cockburn et al., 1999), where the employer wants the employee to perform tasks beneficial in both the long-term perspective for the firm but also tasks beneficial in the short term. In real estate management, tasks such as customer relations and maintenance ought to be beneficial, for the owner, in a long-term perspective, whereas tasks as renewing contracts and new leases should be considered as beneficial in the short perspective (see, for example, Abatecola and Cafferata, 2014, Abdullah et al., 2011; Lindholm and Nenonen, 2006; and Lützkendorf and Speer, 2005). For example, it might be more rational for the individual real estate manager to prioritise a new lease before conducting a service meeting with a current customer. This is because the owner cannot observe the quality time with the customer. However, a new lease is directly quantified through less vacancies and higher rental income. This behaviour can, to some extent, be regulated through different incentive schemes or contracts (Williamson, 1975), depending on what the real estate owner wants the manger to prioritise. Theses incentives can be designed to be individual or on team/group basis (Lee et al. 2015). But as Azasu (2011 and 2009) states, the real estate manager's work is multidimensional, and it consists of tasks that are both measurable as well as non-measurable, but the later ones are still as important. This leaves us with either an incomplete contract or an incentive scheme.

Gibler and Black (2004) add another circumstance to the incentive problem in the case when the real estate management service is outsourced. In this case, the service provider is the one 
with specialist knowledge, and a case of information asymmetry regarding the real estate manager's tasks arises as well.

\subsection{Outsourcing in real estate management context}

Outsourcing is defined as contracting-out services that previously were performed in-house (Atkin and Brooks, 2015). The basic arguments for outsourcing a service is if the service is not a core business and if you can by the service on the market to a lower price. Arguments that can be traced back to Coase 1937) and to Penrose (1959) "Resource Based View of the Firm".

As Usher (2004) points out there are different pros and cons if organising the management inhouse or outsourcing it. Usher (2004) outlines two critical success factors for outsourcing; relationship and contract formulation. Kadefors (2008) conclusion, regarding the Swedish market, stating that good relations do compensate for incomplete contracts goes hand in hand with his conclusion.

Manning et al. (1997) approaches the question of which management functions that should be outsourced, concluding that functions of more strategic nature, value crating, are not to be outsourced. Considering what functions that are on a strategic level or not Perera et al. (2016) provides a clear overview based on Jensen (2011) scheme. The traditional Swedish real estate manager function can be fitted between the strategic and tactical function in relation to Perera et al. (2016) framework. But as Palm (2013) concludes; as both forms of organising the management has coexisted in Sweden for several years without outcompete the other. Instead the different pros and cons, as outlined by Usher (2004), appeals to different real estate owners.

\section{Research design and methodology}

The base of this article is an interview study conducted in 2014. The concern of the study was to identify how the decisionmakers have created incentives for the real estate management organisation to prioritise the right tasks. By investigating the top-management's view regarding what information they prioritise and consider important and, at the same time, investigating the management teams' work and perception of incentives to perform different tasks, an understanding of possible risks of post-contract transaction costs has been pinpointed.

\subsection{Data collection}

A selection of six real estate owning companies was made, where three have an in-house management and three have an outsourced management. The selection was supplemented with the service partners (three different companies) for the three real estate owning companies with an outsourced management. In total, nine companies were included. Six decision makers, all from different real estate owning companies, and 13 persons from the real estate management organisations (six from in-house management and seven from outsourced management) were interviewed. In total, 19 respondents were interviewed for the study. This selection was made, as defined by Patton (2002) and Eisenhardts (1989), through a stratified purposeful sampling. All companies included in the study are larger companies with the ability to have an in-house real estate management organisation. This choice was deliberately made to ensure the same basic conditions regarding the ability to organise the management. Furthermore, a limitation on what real estate the companies own was also made. All the companies have their focus on the commercial real estate market, which ensures that all companies work in a competitive market without regulation as in the housing market. 
The three companies with in-house management are two domestic, institutionally owned companies with regional offices in Malmö and head office in Stockholm, and one listed company with head office in Malmö. They are all large companies in the region with a clear, outspoken focus on office premises. This selection were done primarily regarding their size. These three companies represented, at the time of the study, the three largest real estate companies owning and managing office premises in Sweden.

The three companies with outsourced management are two domestic, institutionally owned companies with their real estate divisions based in Stockholm, and one international, institutionally owned company with their regional office in Malmö. These three companies were chosen due to the fact that they are the only three real estate companies with focus on office premises, that are large enough, in each region, to be able to carry their own real estate management organisation, but has it outsourced. The three service providing companies are all large companies: two have international ownership and one is Swedish. These were chosen because being the service partner of the real estate companies with outsourced management.

The selection of respondents within the companies were done regarding the organisational settings. In every company an entire management team, together with the decision-maker were selected. This was to ensure that the study would consider the same organisational and/or contractual setting.

Before the interview study was conducted a test study was initiated with one real estate-owning company representative and one service partner company representative. This was done to be able to evaluate the interview themes developed from the literature regarding. As the respondents knew this was a test study they were free-spoken and gave feedback regarding what to think about and what to look out for as being only a rhetoric answer and not their sincere opinion. This enabled me to be prepared with more in-depth follow-up questions for each theme, something that otherwise would have been developed ongoing during the study and not in advance. Furthermore, the test study enabled me to be confident knowing that the research question were relevant also for the industry.

Table I. Included respondents

\begin{tabular}{|l|c|c|c|}
\hline & Decisionmakers & Managers & \\
\hline In-house & 3 & 6 & 9 \\
\hline Outsourced & 3 & 7 & 10 \\
\hline & 6 & 13 & 19 \\
\hline
\end{tabular}

The interviews with the nineteen firm representatives (six decisionmakers and thirteen management representatives) were conducted during the spring and summer of 2014. They were all conducted at the respectively company's office. All interviews were recorded and transcribed by the interviewer. The design of the interview process was structured as semistructured interviews (Kvale, 1995). The interviews were based on five themes, as elaborated below. These themes were based on the previous research results of Abdullah et al., 2011, Azasu, 2009, and Ellingsen and Johannesson, 2008.

\subsection{Interview themes}

The interviews with the decisionmakers from the real estate owners had, as their starting point, the choice made regarding whether or not to structure the real estate management in-house or to outsource it. As for the interviews with the individuals from the real estate management 
teams, the starting point was a more comprehensive question regarding work tasks and the representatives' placement in the organisation.

The second theme regarded authority. The focus with the decisionmakers was how they delegate authority in their organisation. In the outsourced setting also what authority that are kept within the organisation and what authority are transferred to the service partner firm. During the interviews with the management teams, the focus was, instead, on how they perceive their authority and what kind of decisions they are eligible to make and/or feel comfortable with to make.

The next theme for the interviews concerned regulations, first regarding individual's role within the organisation and second in relation to customers. With the decisionmakers in the outsourced setting also what are regulated in the contract and not were discussed. With the management teams in the outsourced setting the question of their insight in the contracts were discussed as well as if they have the possibility to influence the contracts when they are renegotiated.

The last theme was more open as the respondents were asked to elaborate on their experiences from working within the organisation and if they thought any question or perspective had been neglected.

\subsection{Data analysis}

To enable sorting, interpreting, classifying and coding of the material, all interviews were taped, and the interviewer transcribed all the material. To enable analysis, each real estate owner and management team pairs were considered as a separate case before clustering the three with inhouse management as one and the three with outsourced management as another. This enabled what Eisenhardt (1989) labels 'cross-case patterns'. From there, structures and similarities were crystallised as well as making it possible to highlight differences within the material.

\section{Findings}

This section is divided in three parts where the role and function is first outlined before the budget process is displayed. Third, the incentives for effort is outlined. Each of the three subheading are divided into two: findings within the in-house management setting is displayed before the findings within the outsourced management setting.

\subsection{Role and function}

From the literature (Abdullah et al., 2011), the tasks that the real estate manger are to be performed. But what level of mandate does the individual real estate manager have to perform these tasks? And in what way does that differ if you work in-house or in a service providing company?

\section{In-house management}

All companies included in the study have rules governing purchase. The rules constitute certain amounts for what the individuals, within the organization, have for authority to make purchase or customer promises. The three different companies also gave a somewhat similar picture.

This coherent picture from the respondents, regarding rules of purchase, stipulates a large mandate for the real estate managers and a smooth process. Generally, the individual real estate manager has a mandate for purchase up to 35,000 euro before having to ask her superiors for more. When considering larger amounts, there seems to be a rather flexible process for 
investment decisions, where the managing director, in a rather informal way, is informed regarding the premises, what is to be considered to be done in it, and an approximation of the costs. None of the included companies has any formal documents to be filled out nor any guidelines for what kind of information that is to be reported or how. The managing director of one of the companies stated that standardised guidelines has been a question and that the coworkers have requested some kind of guidance, but that he preferred this kind of more open handling. The interesting thing is that all parties refer to investment decisions and how the organisation deals with them as on-going processes where a great deal of trust and informal decision paths are permanented. One individual real estate manager displays this flexibility and informality of the process as follows:

We have a delegation list where I have the right to sign up to $35 \mathrm{k}$ euro. After that, I have to take it with my regional manager. Anyhow, I usually knock about investment decisions with him since we sit directly opposite of each other and since we have such a small organisation and such a tight organization. So we knock about these kinds of questions over the desk, and then he trusts me, and I will run the case all the way to the finish line.

(Real estate manager, owning and managing company)

This demonstrates that the individual real estate manager has the full economic responsibility for both the income and the cost side. Regarding the mandate for the individual real estate manger they do seem to have rather large mandates. Also the decision-making process seems to be smooth with a quick check-up even when dealing with rather large sums.

The investment process is by the respondents described as rather informal and simple, where the decision maker seem to put a great deal of trust in the management organisation.

\section{Outsourced management}

In the case of outsourced management, the tasks and mandates for the service partner firm is regulated in the contract between the two partners. The respondents from the service providing companies all gave a similar picture regarding the contract as a governing document that you as an individual are forced to relate to and if working in different contracts, for different real estate owners, you are forced to bear in mind what contract this customer belongs to so that you treat the and promise in according to the right contract. Because as one head of real estate in one of the service partner companies concluded that you as a consultant are not allowed to invest time or money in a project where the client are not willing to pay for it even if you can see that the owner would gain on it in the long run

Another concern that were highlighted by all respondents, in one way or another, is the complexity of working in a service providing company where you are perceived as delivering service from both your principal (real estate owner) and the end customer (tenant) but at the same time have to be loyal to your employer. It can be hard determining whose party to take, the tenants, real estate owners or the company you work for. One real estate manager elaborate this complexity:

It is quite special do to what we as service partners have two customers, where the way to satisfy them are often completely different. It is kind of tricky but on the other hand, in my case I have more or less always worked in this kind of setting. But I know colleagues in the company where there has been some trouble, when individuals think that they do great deals. But you can do great 
deals for the real estate owner but our company will not come out so well and maybe not the tenant either. So that can be a bit tricky to know what hat you are wearing. But as I said I have worked with it for quite a while so for me it works ok.

(Real estate manager, Service partner company)

The citation above give that the contract, constitutes what you as a real estate manager in a service partner company have for mandate, and should prioritise. In practice the individual real estate managers mandate are handled through the invoice system. There are specific levels within the invoice system securing the ability for the real estate owner to have a sound cashflow management. Furthermore, there are, within the contract, clearly outspoken limits for what you as service partner are allowed to do. One head of real estate, from one of the service partner companies, explains it as:

We have a limit on 3,000 Euro without asking. Above that we have to ask the client. Consequently, if we have someone who is interested to move in but we need to invest $10^{\prime}$ euro first, then we will calculate and set up the calculation. We prepare the decision, we prepare the economic decision making errand and make sure to get to a positive result based on the client's way to calculate or our way to calculate if the real estate owner has agreed on it. If we get a green light, then we can start the actual process.

(Head of real estate, Service partner company)

The citation above regarding the limit of the individual's mandate pinpoints that the individuals are rather governed without possibility to make any promises to tenants. At the same time all respondents' whiteness on the fact that there is a clarity regarding how things are to be dealt with and what they are allowed to do and not to do.

The citations above show on a rigid process before investment and that most decisions lie on the real estate owner to make. The real estate managers and the service partner organisation act more or less as a preparatory instance before the decision and executer after decision.

\subsection{The budget process}

As Azasu (2009) concludes, most Swedish real estate companies are budget driven, this question were central to investigate to be able to understand how the different organisations structure their work.

In-house management

The budget process in the in-house management organizations all follows the same procedure. It is the individual real estate manager's task to produce a budget for respectively real estate she is responsible for. She is responsible for both income and expenses. They describe the budget process as an on-going process for the whole first part of the autumn. It all starts with the senior management constitutes certain parameters as prognoses of inflation, fees for electricity and that kind of parameters for input in the budget. To this company goals also come into play. It is then up to the individual real estate manager to develop a budget house for house. These different budgets are then aggregated in each region and the region manager takes oven the process developing a regional budget that is delivered to the managing director. In this process all respondents witness on that a negotiation between the one that has compiled the budget and the senior management is included. However, this negotiation is described more $\mathrm{s}$ a conversation where you are to motivate the numbers and give a status update and not a 
situation where you are told to cut back on expenses, instead there are a focus on how to improve on the income side. The regional manager in the company describes this working procedure below.

My role is, what can I say; more comprehensive and I put some frameworks and so. Actually the main framework coms from the finance side but we can govern them somewhat anyhow. But every real estate manager does her own budget for each and every real estate and then I will go through them. Mainly I go through the key performance indicator and compare them with previous years. So it is both to be a discussant and to be questioning and challenging. Because the basic of all this is that our real estate managers should handle this property as it were their own. That is the key.

(Regional manager, Owning and managing company)

The process is characterised by a low degree of govern from the decisionmaker although this seem to be the only formally written document from the real estate manager. The budget process is interpreted in the in-house management setting as a task where the individual real estate manager has the whole responsibility and can influence the future work to a high degree. The managing director only delivers the framework, mostly regarding external factors. After that the senior management, managing director. and regional manager more or less leaves the process to the real estate managers and only remains as discussion partners and support.

\section{Outsourced management}

The budget process in the outsourced management organisation all follows the same procedure. The real estate owning company will provide a framework including prognosis of inflation together with preferred yield and level of investment. Besides the provided framework a strategic document, consisting of an evaluation and a plan for each property, is provided by the real estate owner stating the long-term objectives for the property. This strategic document, together with the provided framework, act as a basis for the real estate manager while conducting the budget for every single house. Together with the technicians input regarding technical standard the real estate manager creates both a one-year and a three-year budget. In some contracts also a five-year budget is developed but it is always the one-year budget that is the most influential one for the real estate manager since it, together with the strategy document, lies the field for the forthcoming everyday work. These budgets are aggregated up by the head of property and controller at the service partner company, after handing it over to the real estate owner the budget proposal is kneaded back and forward a couple of times before getting a final approval. This leads to a budget per real estate and on account level. One real estate manager, from a service partner, describes this working procedure:

We start to work on that in September and it is finalised from our side in October. Then it goes up to Stockholm to be compiled and after that it goes to the real estate owner who then looks at it and say that we want a higher yield than we have presented and then it is returned to us. At that stage it is almost impossible to do anything to the income side. Only if you have signed a new lease meanwhile but normally you only get to look at the expenses and then you in principle have to postpone maintenance. (...) It all comes down to being able to motivate what you want to do. Basically it comes down to be able to motivate and argue so that you get as large piece of the cake to maintain your real estate as possible. But it can go either way. I have noticed that some year they have cut the expenses $10 \%$ all over. But describing it as some kind of 
bargaining situation, even if you are the weaker part, is probably the best description of the budget process.

(Real estate manager, service partner company)

The description above indicates a rather controlled process from the real estate owners side. At the same time the budget process in the outsourced setting seems to be characterised as a bargaining process where the owner want as high yield as possible and the real estate manager want as high maintenance budget as possible.

\subsection{Incentives for effort}

Research (see for example Ellingsen and Johannesson, 2008) state that we are motivated by both monetary and non-monetary incentives to perform. It can be by a bonus for reaching a goal or the possibility to get a promotion when performing well.

\section{In-house management}

On company level none of the companies have any bonuses on neither individual nor group level. On the other hand, they have collective bonuses tied to company performance. These company bonuses are in all three cases tied to two different parameters. The firs parameter is the economical outcome of the company. Either the company set a monetary, yield, goal or, as in two of the cases, set a goal that they are to generate $1 \%$ better than SFI (Swedish real estate index). The other parameter is customer satisfaction and linkage to a satisfied customer index where the company are to perform better than last year. As everything is measured on company level the individual employee cannot fully link her performance to the possibility to reach the goal and earn the bonus.

Considering non-monetary incentives, one can be the possibility of promotion. All three companies in the study has a policy for internal-promotion. But the fact that the organisation in the Swedish real estate industry is non-hierarchic prevents promotions and one of the real estate managers stated:

The company has a very flat organisation. It's only two persons between the managing director and me. Of course there are a possibility to keep at performing and become head of real estate by time, it's like that. Or maybe you want to work with leasing or some of the other coordination functions. We had a small reorganisation earlier this year. Now we have two new head of real estate. Those were requited internally and that's very positive.

(Real estate manager, Real estate owning and managing company)

The policy by the decisionmaker to, when possible, requite internally seems to be considered as an incentive to perform, even if there want be promotions every year. But as they are aware of the non-hieratic organisation in the industry they thereby have patience regarding promotions. One contributing factor can be that they would not get a higher position in any other real estate company as these companies as well has a non-hieratic organisation, and possibly an internal-promotion policy.

Outsourced management

In the outsourced management setting bonuses work in two levels. First it's between the real estate owning company and the service providing company (business-to-business level). Second it's within the service providing company, between the company and its employees, where the employees can have the possibility for bonus. 
On the business-to-business level all of the contractual settings had bonus linked to new rentals. Every empty space they managed to lease generates a bonus. In general, it is a percentage of the first years rent that is paid in bonus. A second bonus, on the business-to-business level, is a bonus described as a subjective bonus. The real estate owner decides this subjective bonus, it cannot be calculated, since it is not tied to any goals. Instead it is based on soft values and up to the real estate owner company to decide upon if it should be paid or not. One service partner representative describe the possibility for bonus as follows:

We have a kind of subjective bonus in the contract, we do. It can fall out but there are no clear criteria to reach these no goals or anything that state that how you get that bonus. But there is a possibility to get a subjective bonus. (Head of property, Service partner company)

On the business-to-business level there are two types of possibilities to earn a bonus. One that are directly tied to new leases, $100 \%$ predictable, and one subjective that are impossible to calculate and is dependent on the owner's conception of the service partner's delivery. The second kind of arrangement for bonuses in the contractual setting where the service partner company cannot link her performance to the bonus must be characterised as a week incentive.

On company level within the service partner company the possibility to earn bonus are small. None of the service partner companies have any bonuses for their employees regarding monetary bonuses. Furthermore, no company, of the service partner companies, see the question of bonus for their employees as a motivation factor. Only one respondent consider it as a possibility, or need, to be able to recruit new young employees.

Considering non-monetary incentives, the service partner companies has the same flat organizations as the real estate owning companies preventing promotions. There is also a similarity regarding promotion policies. One of the service partner companies even had an outspoken promotion strategy where every middle and senior manager are to assign what coworker that are to take her place if something happens.

Schematic you can illustrate incentives for effort in the two organisational settings by what mandate the individuals have and what incentives there are in the organisation.

Table II. Incentives in different organisational settings

\begin{tabular}{|l|l|l|}
\hline & In-house management & Outsourced management \\
\hline Mandate & 35,000 Euro (rather large) & 3,000 Euro (rather low) \\
\hline Monetary incentives & $\begin{array}{l}\text { Bonus based on company } \\
\text { level, equally for all } \\
\text { employees. }\end{array}$ & No bonuses on manager level \\
\hline $\begin{array}{l}\text { Non-monetary } \\
\text { incentives }\end{array}$ & $\begin{array}{l}\text { Freedom with responsibility. } \\
\text { Internal promotion/recruitment } \\
\text { policy }\end{array}$ & $\begin{array}{l}\text { Internal promotion/recruitment } \\
\text { policy }\end{array}$ \\
\hline
\end{tabular}

From Table II we can see that the management organisations are motivated in both organisational settings but in different manner. It is apparent that there are more incentives in the in-house setting as there are a chans of bonus, even if it is on company level and not individual. Moreover, in the in-house setting the management teams, besides of internal 
promotion, also have a larger freedom with responsibility as well as large mandate. However, we can only observe what incentives there are, not how strong or attractive the real estate owner has managed to make them.

\section{Discussions}

In the in-house setting the decisionmakers seem to delegate most of the authority to the real estate managers, giving them large mandates and control over the budget process. Together with the statement by one of the managing directors "We want them to act as they are the owner of the real estate" indicates a large portion of trust. Trust that results in a freedom with responsibilities. This kind of freedom with responsibilities relates to Gibbons (1998) but where the decisionmaker (principal) does not restrict the individual real estate manager (agent) in her actions or try to stir her into a preferred action related to a bonus. Instead this freedom with responsibilities is used to motivate the employee to work with both tasks that are benefitting on the short- and long-term perspective, just as Cockburn et al. (1998) emphases. However, since there is no monitoring the decisionmaker are to have a large portion of trust in the employees' ability and their moral to perform. Furthermore, there is a lack of bonuses on individual level. There are only bonuses available on aggregated level which risk to mitigate the incentive a bonus otherwise could be. Considering Lee et al. (2015) conclusion regarding team bonuses where a supporting behaviour is emphases by a team bonus, we must remember the rather small units and large responsibilities of the property manager leaving us with less incentives to work in teams.

In the outsourced setting the contracts regulate reporting of leases and yields and that's what the service partner company is evaluated by. Azasu (2011) conclude that to be able to motivate the real estate manager to perform in all of her tasks, quantifiable and non-quantifiable, incentive schemes need to be developed. Otherwise an incomplete contract is at hand. In our case there are no incentive schemes tied to the contracts, so we have an incomplete contract. The service partner company does not have any incentive to prioritise customer relations, or other non-quantifiable tasks, in the short run. They do on the other hand in the long run, since they are measured by the yield of the properties. The yield is tied to the rents and low vacancies drive higher yields so they do have an incentive, in the long run to work with customer relations. But if we look at the contractual settings we can see that the contracts between the real estate owner and service partner firms are shorter than the leasing contracts for the tenants. This could work in the opposite direction, not motivating the service partner company to work with customer relations. Although, it does indicate that there are incentives, like those proposed by Cockburn et al. (1998), but not that well designed. The incentive to work for good customer relation, long-term questions, could be much stronger designed in the contract between the real estate owner and the service partner company. The way the incentives in the contract is designed to day do risk an opportunistic behaviour from the service partner side prioritising the tasks that show result directly before investing time in tasks/actions promoting long-term questions that does not give any direct outcome in the short perspective. Furthermore, the study support Sundsvik (2006) conclusion regarding the lack of bonuses tied to these kind of contracts, as none of the included cases has bonuses in their contracts.

Then what motivates the individual real estate manager to perform in the complexity of tasks as described by Abdullah et al. (2011)? One of the real estate managers stated above that for him as a consultant he needed to outperform every day so that the real estate owner did not want to change service partner. In some sense it can be seen as performance under fear of losing your job rather than a positive incentive to perform. At best one could interpret it as a pride in 
his work to show that the real estate owner chooses to buy the services rather than manage it in-house. This occurrence can also be seen in Ellingsen and Johannessons (2008) experimental game-theoretic model, where pride works as incentive for effort.

\section{Conclusion}

As discussed above there are advantages as well as disadvantages with the two different ways to organise the real estate management. Even if the study only concerns six companies and their real estate management organisations, all of them showed upon the same advantages and disadvantages. That is something that do indicate that the result can be generalised, at least within the Swedish context. These advantages and disadvantages are summarised in Table III:

Table III. Advantages and Disadvantages

\begin{tabular}{|c|c|c|}
\hline & Advantages & Disadvantages \\
\hline In-house & 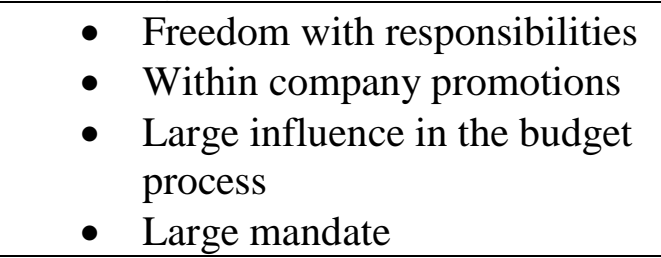 & $\begin{array}{l}\text { - No direct possibility to } \\
\text { influence bonus } \\
\text { - One eyed budget }\end{array}$ \\
\hline Outsourced & $\begin{array}{l}\text { - Within company promotion } \\
\text { - Clear regulations of mandate } \\
\text { - Clear regulation of work tasks } \\
\text { - Organisational flexibility }\end{array}$ & $\begin{array}{l}\text { - No bonuses available } \\
\text { - Small mandate }\end{array}$ \\
\hline
\end{tabular}

In the in-house setting one of the regional managers stated that they wanted their managers to act, as they were owners of the houses that they managed. Together with the fact that these real estate managers do have large mandates, in terms of coverage rights, and a more informal decision environment stipulates a great deal of trust from the decisionmakers side. You could say that this trust acts as an incentive for effort where responsibility begets accountability.

Still concerning the in-house setting there are a risk in the budget process since no outside part checks the budget there are no incentive for the individual real estate manager to push the boundaries and outperform. Together with the fact that there are no bonuses tied to individual performance there are definitely a low degree of incentive for effort in the in-house setting

Considering the outsourced setting there are clear incentives for the real estate manager to prioritise leasing questions. At the same time there are an inherent risk for opportunistic behaviour in the sense that the individual manager has more than one party to serve. As one of the respondents stated "individuals that think that they do great deals, but you can do great deals for the real estate owner but our company will not come out so well and maybe not the tenant either." Implicitly he states that the individual should not have done that, instead she should have acted for the benefit of her company. At the same time another real estate manager states, "you as a consultant are forced to outperform every day, otherwise they will change service partner." These two citations together with low degree of influence of the budget process and that leases are promoted gives a risk for opportunistic behaviour in sense of the real estate manager to neglect the current tenants and focus on new leases. That can in the long run leave the real estate owner company with high tenant turn around. One way to mitigate the risk of opportunistic behaviour is to implement an extension option in the contract. This extension option would work as an incentive for the service partner firm to work with questions/tasks/activities related to long-term perspectives as customer relations. 
All in all, we can conclude that there are differences between how the real estate manager function is motivated to perform whether it is organised in-house or is outsourced. Both ways of organising the real estate management has its pros as well as cons. Organising with in-house management may render shorter decision paths and less administration. But it will leave the decisionmaker in a weaker position governing and ability to be flexible concerning service in real estate management. Organising with outsourced management on the other hand gives larger overhead costs and more administration. But it will give the decisionmaker greater possibility to manage, govern and the flexibility if not satisfied with service provided.

Reconnecting to the previous research of incentives in the Swedish real estate industry we can conclude that we as Azasu (2011 and 2009) state are left with incomplete contracts. But Azasu furthermore conclude that this imply measurable incentive schemes, something that is not found in this study. Furthermore, given the information above one could for the commercial real estate industry argue for the same need as Too and Too (2010) identify in the infrastructure asset management: A strategic approach to enhance performance. Aligning with the resource-based view, firms must identify their core capabilities and from those derive the key process, and carefully designing an incentive scheme. It is not until then the choice between in-house or outsourced management can become successful in terms of better performance.

\section{Implication for further research}

The result of the study raises the question regarding how the customer and tenant experience the different management forms. Do they consider the real estate manager in the in-house setting to have mandate to carry out tasks and act as she is the owner of the building? At the same time do the customer and tenant in the outsourced setting experience that the individual real estate manager is just a middleman that have to gain approval for every question before making decision?

\section{References}

Abatecola, Gianpaolo, and Cafferata, Roberto. (2014), Real estate management: what boundaries? A European approach, International Journal of Globalisation and Small Business, Vol. 6, Nos. 3/4, pp. 163-176.

Abdullah, Shardy, Arman, Abdul, Razak, and Abd, Hamid, Kadir, Pakir. (2011), The characteristics of real estate assets management practice in the Malaysian Federal Government, Journal of Corporate Real Estate, Vol. 13 No. 1, pp. 16-35.

Atkin, Brian, and Brooks, Adrian. (2015), Total facility management $4^{\text {th }}$ ed., Wiley Blackwell, Azasu, Samuel. (2009), Own Rewards and Performance of Swedish Real Estate Firms, Compensation \& Benefits Review, Vol. 41, No. 4, pp. 19-28.

Azasu, Samuel. (2011), Ownership and Size as Predictors of Incentive Plans within Swedish Real Estate Firms, Property Management, Vol. 29, No. 5, pp. 454-467.

Baker, George, Gibbons, Robert, and Murphy, Kevin, J. (1994) Subjective Performance Measures in Optimal Incentive Contracts, Quarterly Journal of Economics, Vol. 109, pp. 11251156.

Baker, George. (1992), Incentive contracts and performance measurement, Journal of Political economy, Vol. 100, No. 3, pp. 598-614.

Bonner, Sarah, E., and Sprinkle, Geoffrey, B. (2002). The effects of monetary incentives on effort and task performance: theories, evidence, and a framework for research, Accounting, Organizations and Society, Vol. 27, pp- 303-345. 
Coase, Ronald, H. (1937), The Nature of the Firm, Economica, No. 4, pp. 386-405.

Cockburn, Iain, Hendersson Rebecca, and Stern Scott. (1998), Balancing Incentives: The Tension Between Basic and Applied Research, Working paper 6882, National Bureau of Economic Research.

Eisenhardts, Kathleen. (1989), Building theories from case study research. Academy of management review, Vol. 14. No 4, pp. 532-550.

Ellingsen, Tore, and Johannesson, Magnus. (2008), Pride and Prejudice: The Human Side of Incentive Theory, American Economic Review, Vol. 98, No. 3, pp. 990-1008.

Fisher, Joseph G., Peffer, Sean, A., and Sprinkle, Geoffrey, B. (2003), Budget-Based Contracts, Budget Levels, and Group Performance, Journal of Management Accounting Research, Vol. 15, pp. 71-94.

Freybote, Julia, and Gibler, Karen, M. (2011). Trust in corporate real estate management outsourcing relationships, Journal of Property Research, Vol. 28, Iss. 4, pp. 341-360.

Gibler, Karen, M., Black, Roy, T. (2004), Agency risks in Outsourcing Corporate Real Estate Functions, The journal of Real Estate Research, Vol. 26, No. 2, pp. 137-160.

Gibbons, Robert. (1998), Incentives in Organizations, The Journal of Economic Perspectives, Vol. 12, No. 4, pp. 115-132.

Graham, John Edward, Galbraith, Craig, and Stiles, Curt. (2014), Real estate ownership and closely-held firm value, Journal of Property Investment \& Finance, Vol. 332, No. 3, pp. 229243.

Holmström, Bengt, and Milgrom, Paul. (1991), Multitask Principal-Agent Analyses: Incentive Contracts, Asset Ownership, and Job Design, Journal of Law, Economics, and Organization, Vol. 7,pp. 24-52

Hätönen, Jussi, and Eriksson, Taina. (2009), 30+ years of research and practice of outsourcing, Journal of International Management, Vol. 15, No. 2, pp. 132-155.

Jensen, Per, Anker. (2011), Organisation of facilities management in relation to core business, Journal of Facilities Management, Vol. 9, No. 2, pp. 78-95.

Kadefors, Anna. (2008), Contracting in FM: collaboration, coordination and control, Journal of Facilities Management, Vol. 6, No. 3, pp. 178-188.

Klingberg, Beate, and Brown, Roger, J. (2006), Optimization of residential property management, Property Management, Vol. 24, No. 4, pp. 397-414.

Kvale, Steinar. (1995), Den kvalitativa forskningsintervjun. Studentlitteratur, Lund Vol. 97, pp. 561-580.

Lazear, Edward. (1989), Pay Equality and Industrial Politics, Journal of Political Economy, Lee, Chun-Chang, Ho, Yu-Ming, and Chang, Hsiang-Chi. (2015). The Impact of Team Bonus and Team Scale on Helping Effort: An Application of Hierarchical Generalized Linear Models, Journal of Statistics \& Management Systems, Vol. 18, No. 1 \& 2, pp. 85-119.

Lindholm, Anna-Liisa, and Nenonen, Suvi. (2006), A conceptual framework of CREM performance measurement tools, Journal of Corporate Real Estate, Vol. 8, No. 3, pp. 108-119. Lok, Ka, Leung, and Baldry, David. (2015), Facilities management outsourcing relationships in the higher education institutes, Facilities, Vol. 33, No. 13/14, pp. 819-848.

Lützkendorf, Thomas, and Speer, Thorsten M. (2005), Alleviating asymmetric information in property markets: building performance and product quality as signals for consumers, Building research \& Information, Vol. 33, Iss. 2, pp. 182-195

Manning, Chris, Rodriguez, Mauricio, and Roulac, Stephen, E. (1997), Which Corporate Real Estate Management Function Should be Outsourced, The Journal of Real Estate Research, Vol. 14, No. 3, pp. 259-274

Marona, Bartlomiej. (2013), Use of the Agency Theory to Analyze the Commissioning System of Commune Real Estate Management, Real Estate Management and Valuation, Vol. 21, No. 3, pp. 43-50. 
Milgrom, Paul, and Robers, John. (1992), Economics, Organisation and Management, Prentice Hall, Upper Saddle River, New Jersey.

Milgrom, Paul, and Roberts, John. (1986), Relying on the information of interested parties, The RAND Journal of Economics, Vol. 17 No. 1, pp. 18-32.

Patton, Michael, Quinn. (2002), Qualitative research \& Evaluation methods 3ed. Sage Thousand Oaks.

Palm, Peter. (2013). Strategies in Real Estate Management: Two Strategic Pathways, Property Management, Vol. 31, Iss. 4, pp. 311-325.

Penrose, Edith. (1959), The Theory of the Growth of the Firm, $4^{\text {th }}$ ed. Oxford, University Press. Perera, B.A.K.S., Ahmed, M.H.S., Rameezdeen, Raufdeen, Chileshe, and Hosseini, M. Reza. (2016), Provision of facilities management services in Sri Lankan commercial organisations Is in-house involvement necessary?, Facilities, Vol. 34, No. 7/8, pp. 394-412.

Prendercast, Canice. (1999), The Provision of Incentives in Firms, Journal of Economic Literature, Vol. 37, No. 1, pp. 7-63.

Sanderson, Danielle, C. (2014), Treating the Tenant as a Customer: Can good Service Improve Real Estate Performance? Working papers in Real Estate \& Planning 04/14, Henley Business School.

Sanderson, Danielle, C. (2015), Determinants of Satisfaction Amongst Occupiers of Commercial Property, European Real Estate Society Conference, Istanbul June 2015, Book of preceding's, pp. 149-170.

Sanderson, Danielle, C., and Edwards, Victoria, M. (2014), What tenants want: UK occupiers' requirements when renting commercial property and strategic implications for landlords, American Real Estate Society Conference, San Diego April 2014.

Sanderson, Danielle, C., and Edwards, Victoria, M. (2016) Determinants of satisfaction amongst tenants of UK offices, Journal of Corporate Real Estate, Vol. 18, Iss. 2, pp. 102131.

Shapiro, Carl, and Stiglitz, Joseph, E. (1984), Equilibrium Unemployment as a Worker Discipline Device, American Economic Review, Vol. 74, No. 3, pp. 433-444.

Sirmans, Stacy G., Sirmans, C. F., and Turnbull, Geoffrey K. (1999), Prices, incentives and choice of management forms, Regional Science and Urban Economics, Vol. 29, pp. 173-195. Sundsvik, Leif. (2006), Erfarenheter av driftentreprenad, Diskussionsunderlag $i$

upphandlingsprocessen, UFOS, Stockholm.

Too, Eric G., and Too, Linda. (2010), Strategic infrastructure asset management: a conceptual framework to identify capabilities, Journal of Corporate Real Estate, Vol. 12, Iss. 3, pp. 196208.

Usher, Neil. (2004) Outsource or in-house facilities management: The pros and cons, Journal of Facilities Management, Vol. 2, No. 4, pp. 351-359.

Williamson, Oliver E. (1975), Markets and Hierarchies Analysis and Antitrust Implications. Free Press cop. New York. 